\title{
Protein Nutritional Value of Ground Okra Seed in Rat Feeding Trials ${ }^{1}$
}

\author{
P. A. Savello, F. W. Martin, and J. M. Hill ${ }^{2}$
}

\begin{abstract}
The relative protein nutritional value of okra seed protein was estimated by protein efficiency ratio and relative protein value assays with growing rats. The form in which okra seed meal was presented in the diet influenced the amount that was eaten, and, hence protein efficiency ratio, but relative protein value compensates for this difference. Freshly ground okra seed retarded growth of rats but heating the ground seed meal or aging it up to 4 weeks after grinding reduced or eliminated this inhibition. The relative protein value of heated or aged ground okra seed is $70 \%$ of a casein control. The relative protein value of okra seed protein compares favorably to that of other proteins from seeds.
\end{abstract}

\section{INTRODUCTION}

Okra has the potential of becoming a new, high protein, high oil seed crop for the tropics and can produce yields that rival those of other protein and oil producing crops (4). In tests of a technique for home scale use of okra seed, Martin and Ruberté (5) ground the seed with a hand mill and separated two fractions, chiefly hulls and kernels, by sieving. The okra meal produced contained $33 \%$ protein and $32 \%$ oil. This meal was used as a partial substitute for wheat flour and cooking oil to prepare a wide variety of baked products. A vegetable curd can be made from the seed that is high in protein and oil, and is as organoleptically acceptable as soybean curd or tofu (6).

The value of okra seed as an animal feed was tested by Karakoltsidis and Constantinides (2), who demonstrated the protein efficiency ratio (PER) of ground okra seed of 2.52, as compared to 2.50 for casein. While questionably high, this PER value suggests the high value of protein of ground okra seed and invites broader testing.

In these studies ground okra seed has been used as a feed for weanling rats to test its relative protein value (RPV).

\section{MATERIALS AND METHODS}

Two laboratory animal feeding studies were performed to determine the value of the protein of ground okra seed in promoting growth in laboratory rats. The feeding studies evaluated 1) the RPV and the PER

${ }^{1}$ Manuscript submitted to Editorial Board October 18, 1983.

${ }^{2}$ Formerly Master's degree student, Brigham Young University, Provo, UT. Present address: Schreiber Foods, Inc., Green Bay, WI; Horticulturist, Tropical Agriculture Research Station, Mayagüez, Puerto Rico; Department of Food Science and Nutrition, Brigham Young University, Provo, UT. 
of okra seed protein compared to control diets containing casein, and 2) the effect on protein nutritive value of aging and heating the ground okra seed meal.

In the first trial the RPV of okra seed protein was evaluated according to Hegsted et al. (1) and Samonds and Hegsted (7). Thirty-six weanling rats of the Sprague-Dawley strain were given a 3-day adaptation period before the feeding trial. The adaptation diet consisted of a powdered $7 \%$ casein diet, similar in composition to the $7 \%$ casein diet used during the test period. All subsequent diets (casein control and okra seed meal) contained the following components (with corresponding weight percentage): vitamin mix, $2 \%$; riboflavin, $.002 \%$; thiamin, .0021\%; mineral mix, ${ }^{3} 5 \%$; a protein source (casein ${ }^{4}$ or okra seed meal) that supplied approximately 4,7 , and $10 \%$ dietary protein; corn starch and vegetable oil were added in the necessary proportion to make each diet isocaloric at 440 calories/100 grams of diet. The casein control diets contained noncaloric cellulose (3\%) for added dietary fiber.

The rats were divided into nine groups of similar weight (10 g maximum weight range within each group) containing four rats each. Three groups were fed powdered diets containing approximately 4,7 , and $10 \%$ casein. Kjeldahl analysis of these diets indicated the protein content to be 3.8 , 6.6 , and $8.8 \%$ protein $(\mathrm{N} \times 6.25)$, respectively.

The remaining six rat groups were fed diets containing approximately 4,7 , and $10 \%$ protein supplied by ground okra seed. Large batches of the three okra seed diets were prepared. Each batch was divided into two parts: one half was maintained as a powdered mixture, the other half was passed through a Wenger model X-5 extruder-cooker to produce an expanded, chunky food product. The extrusion process included steam heating and pressure treatment of the meal. Kjeldahl analysis indicated the protein content to be $4.6,7.4$, and $10.6 \%$ protein $(\mathrm{N} \times 6.25)$ for the powdered okra seed diets and $4.2,7.2$, and $10.0 \%$ protein $(\mathrm{N} \times 6.25)$ for the extruded okra seed diets.

The animals were given food and water ad libitum, three times weekly, for 28 days. The rats were weighed initially and weekly thereafter, although only the initial and final weights were used in determining weight change during the 28-day test period.

Regression line analysis was performed according to Kleinbaum and Kupper (3). Comparison of regression curves for parallelism and yintercept was performed by application of a small sample t-test for parallelism and a small sample t-test for common y-intercept.

The slopes of the regression curves for the okra seed diets (powdered and extruded) were compared to the slope of the powdered casein control

${ }^{3}$ Salt Mixture XIV, Nutritional Biochemicals Company, Cleveland, Ohio.

${ }^{4}$ Vitamin Free Casein, Nutritional Biochemicals Company, Cleveland, Ohio. 
regression curve. This slope ratio of test protein to casein control indicated the RPV of okra seed protein (7).

The 28-day PER values of the three test diets containing approximately $10 \%$ protein levels were calculated after adjustment for the differences in protein contents. The three diets were standardized to a $10.0 \%$ protein level using regression analysis of each diet series. The results are presented in table 1.

Statistical analyses were performed to indicate significant differences of the animal feeding trial data. The Fisher distribution test was utilized to determine any statistical difference among the test values followed by a Newman-Keul pairwise comparison test to indicate any statistically different element(s) within the values under test.

Because the first feeding trial gave a preliminary indication that okra seed meal which had been aged up to 4 weeks promoted faster growth than fresh (non-aged) okra seed meal, a second study was designed to determine if any significant differences existed between aged, fresh, and heated okra seed meal in promoting rat growth.

TABLE 1.-Calculated protein efficiency ratio of okra seed test diets used in rat feeding trial 1

\begin{tabular}{lcccc}
\hline Diet group & $\begin{array}{c}\text { Protein } \\
\text { level }\end{array}$ & $\begin{array}{c}\text { PER at } \\
\text { experimental } \\
\text { protein } \\
\text { level }\end{array}$ & $\begin{array}{c}\text { PER at } \\
\text { standardized } \\
10 \% \text { protein } \\
\text { level }\end{array}$ & $\begin{array}{c}\text { Adjusted } \\
\text { PER }\end{array}$ \\
\hline Okra seed, powdered & $\%$ & & & \\
Okra seed, extruded & 10.6 & $1.54 \pm 0.36$ & 1.52 & 1.05 \\
Casein, powdered & 10.0 & $2.35 \pm 0.17$ & 2.35 & 1.62 \\
\hline
\end{tabular}

Fifteen weanling rats of the Sprague-Dawley strain were fed a powdered $7 \%$ casein diet for an adaptation period of 3 days. All test diets (casein control and okra seed) had a similar composition as described in the first experiment. All diets were in powdered form and contained approximately $10 \%$ protein, the protein source being either casein or okra seed meal.

The rats were divided into five groups of similar weight $(7 \mathrm{~g}$ maximum weight range within each group) of three rats each. One group was fed a casein diet as a control; the remaining four groups were fed four different okra seed meal diets as follows: 1) okra seeds were ground and mixed with all dietary components 4 weeks prior to the commencement of the feeding trial; 2) okra seeds were ground and mixed with all dietary components 2 weeks prior to commencement of the feeding trial; 3) okra seeds were ground and heat-treated at $120^{\circ} \mathrm{C}$ for 3 hours prior to mixing the heated meal with all dietary components; 4) freshly ground okra seed 
meal was mixed with all dietary components on each feeding day to ensure that the animals receiving this diet obtained freshly ground okra seed meal as the sole source of protein.

Okra seed meal diets 1,2, and 3 were stored at refrigerator temperature $\left(4^{\circ} \mathrm{C}\right)$ following preparation and throughout the 21-day feeding trial. Okra seed meal diet 4 was not held under any storage condition as it was prepared and dispensed in a freshly ground state on each feeding day.

Kjeldah analysis indicated the protein content to be $8.9 \%$ protein for the casein control diet and 10.0,9.5, 11.0, and 10.7\% protein for the okra seed meal diets $1,2,3$, and 4 , respectively.

\section{RESULTS}

Figure 1 shows the regression curves of the three diet groups of the first experiment (casein control, powdered okra seed, and extruded okra seed). The RPV for the powdered okra seed and the extruded okra seed diets were each equal to $70 \%$.

Statistical analysis of the regression curves of the powdered okra seed and extruded okra seed diets indicate that there was no significant difference between the respective slopes nor between the respective $y$ intercepts.

Table 2 shows the summaries of the weekly protein consumption of all levels of the three diet groups. During weeks 3 and 4 of the feeding trial the rat groups receiving the extruded okra seed diets consumed a significantly greater protein content than the older two groups. At the 10\% protein level the group receiving the extruded okra seed diet showed a significantly greater weekly protein consumption than the groups receiving the other two diets throughout the feeding trial.

Table 3 shows the weekly weight changes and cumulative weight changes of all levels of the three diet groups. At the $4 \%$ protein level all groups lost weight during the initial 3 weeks of the trial; however, all groups showed slight weight gain during the fourth week. At the 7 and $10 \%$ protein levels the casein group and extruded okra seed group showed positive weight change throughout the trial, the latter diet group indicating higher weight change values. The powdered okra seed diet group indicated a weight loss during the first 2 weeks of the test period followed by a slight positive weight change only during week 3 of the test period $(+0.4 \mathrm{~g}$ at $7.4 \%$ protein and $+9.0 \mathrm{~g}$ at $10.6 \%$ protein $)$. Weight gain was more dramatic during week 4 for this group, during which time the group average weight change was $+7.4 \mathrm{~g}$ at $7.4 \%$ protein level and $+27.6 \mathrm{~g}$ at $10.6 \%$ protein level.

Table 4 summarizes the average weekly protein consumption for each diet group of the second experiment. There were only slight variations 
VOL. LXIX, NO. 1, JANUARY 1985

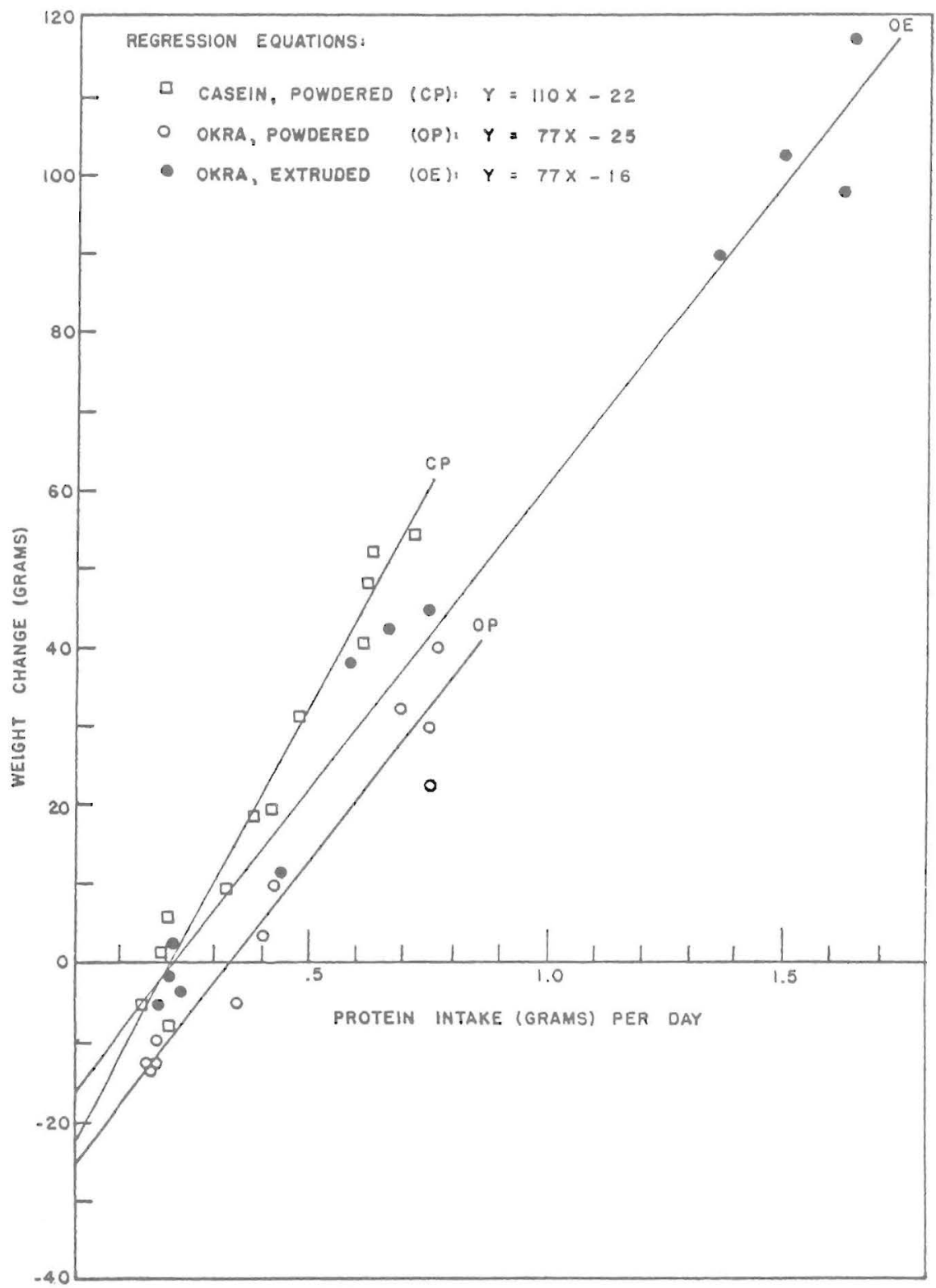

FIG. 1.-Weight change vs. daily protein intake in feeding trial 1. 
JOURNAL OF AGRICULTURE OF UNIVERSITY OF PUERTO RICO

TABLE 2.-Weekly protein consumption of diet groups in feeding trial 1

\begin{tabular}{lrrrrr}
\multirow{2}{*}{ Diet group } & & \multicolumn{5}{c}{$\begin{array}{c}\text { Protein consumption (g) } \\
\text { Week }\end{array}$} \\
\cline { 3 - 6 } & Protein & 1 & 2 & 3 & 4 \\
\hline \multirow{2}{*}{ Casein, powdered } & 3.8 & 1.55 & 1.07 & 1.07 & 1.21 \\
& 6.6 & 2.91 & 2.29 & 2.58 & 3.24 \\
Okra seed, powdered & 8.8 & 4.00 & 3.87 & 4.56 & 5.60 \\
& 4.6 & 1.27 & 1.07 & 1.08 & 1.26 \\
Okra seed, extruded & 7.4 & 2.56 & 2.19 & 2.47 & 3.34 \\
& 10.6 & 3.46 & 3.25 & 5.06 & 8.28 \\
& 4.2 & 1.44 & 1.20 & 1.34 & 1.66 \\
& 7.2 & 3.57 & 3.52 & 4.52 & 4.35 \\
& 10.0 & 5.78 & 8.67 & 13.6 & 15.2 \\
\hline
\end{tabular}

TABLE 3.-Weekly and cumulative weight changes of diet groups in feeding trial 1

\begin{tabular}{ccccc}
\hline & & \multicolumn{3}{c}{ Weight change (g) } \\
Week \\
\cline { 3 - 5 } Diet group & Protein & & 3 & 4 \\
\cline { 3 - 5 } & & 1 and $2^{1}$ & & \\
Casein, powdered & 3.8 & -1.8 & $-0.9(-2.7)^{2}$ & $1.2(-1.5)$ \\
& 6.6 & 4.6 & $4.3(8.9)$ & $10.8(19.7)$ \\
Okra seed, powdered & 8.8 & 17.8 & $11.3(29.1)$ & $19.8(48.9)$ \\
& 4.6 & -11.1 & $-1.8(-12.9)$ & $0.9(-12.0)$ \\
Okra seed, extruded & 7.4 & -5.7 & $0.4(-5.3)$ & $7.4(2.1)$ \\
& 10.6 & -5.2 & $9.0(3.8)$ & $27.6(31.4)$ \\
& 4.2 & -5.8 & $-1.0(-6.8)$ & $4.4(-2.4)$ \\
& 7.2 & 5.9 & $10.7(16.6)$ & $17.1(33.7)$ \\
& 10.0 & 26.2 & $37.2(63.4)$ & $38.5(101.9)$ \\
\hline
\end{tabular}

${ }^{1}$ Weight change at end of 2 weeks of feeding trial.

${ }^{2}$ Cumulative weight changes are in parentheses.

TABLE 4.-Weekly protein consumption of diet groups in feeding trial 2

\begin{tabular}{|c|c|c|c|}
\hline \multirow{2}{*}{ Diet group } & \multicolumn{3}{|c|}{$\begin{array}{c}\text { Protein Consumption }(\mathrm{g})^{1} \\
\text { Week }\end{array}$} \\
\hline & 1 & 2 & 3 \\
\hline Okra seed meal-aged 4 weeks & $2.46^{\mathrm{a}}$ & $4.30^{\mathrm{b}}$ & $3.54^{\mathrm{c}}$ \\
\hline Okra seed meal-aged 2 weeks & $2.75^{\mathrm{a}}$ & $4.53^{\mathrm{b}}$ & $3.31^{\mathrm{c}}$ \\
\hline Okra seed meal-heated & $2.68^{\mathrm{a}}$ & $4.82^{\mathrm{b}}$ & $3.80^{c}$ \\
\hline Okra seed meal-fresh & $3.11^{\mathrm{a}}$ & $4.76^{\mathrm{b}}$ & $3.67^{\mathrm{c}}$ \\
\hline Casein, powdered ${ }^{2}$ & 4.10 & 3.87 & 4.56 \\
\hline
\end{tabular}

\footnotetext{
${ }^{1}$ Values followed by same superscript do not differ statistically at $\mathrm{P}=.05$.

${ }^{2}$ Casein diet data not included in statistical analysis.
} 
among the respective diet groups during each week of the 21-day test period. A statistical analysis (Fisher distribution) was performed to compare the group average protein consumption values for each week. There was no statistical difference among the protein consumption values during each week.

Table 5 shows a summary of the weekly weight change of the diet groups in the second feeding trial. All animals consuming okra seed test diets showed a weight loss during week 1 of the test period. Subsequently, all animals showed a weight gain for the succeeding 2 weeks. The animals that received the fresh okra seed gained less weight during weeks 2 and 3 than the other test groups.

There was no significant difference among the group averages for weeks 1 and 2 (table 5). However, there was a significant difference among the groups average for week 3 . A subsequent pairwise comparison indicated that fresh okra seed meal and okra seed meal that had been

TABLE 5.-Weekly weight change of diet groups in feeding trial 2

\begin{tabular}{lccc}
\hline & \multicolumn{3}{c}{ Weight Change $(\mathrm{g})^{\mathrm{1}}$} \\
& \multicolumn{3}{c}{ Week } \\
\cline { 2 - 4 } & 1 & 2 & 3 \\
\hline Okra seed meal -aged 4 weeks & $-2.93^{\mathrm{a}}$ & $8.03^{\mathrm{b}}$ & $14.07^{\mathrm{c}}$ \\
Okra seed meal-aged 2 weeks & $-2.90^{\mathrm{a}}$ & $8.13^{\mathrm{b}}$ & $9.80^{\mathrm{d}}$ \\
Okra seed meal-heated & $-2.63^{\mathrm{a}}$ & $7.33^{\mathrm{b}}$ & $11.40^{\mathrm{c}}$ \\
Okra seed meal-fresh & $-2.27^{\mathrm{a}}$ & $3.30^{\mathrm{b}}$ & $5.13^{\mathrm{d}}$ \\
Casein, powedered & 9.60 & 8.20 & 11.3 \\
\hline
\end{tabular}

${ }^{1}$ Values followed by same superscript do not differ statistically at $\mathrm{P}=.05$.

${ }^{2}$ Casein diet data not included in statistical analysis.

aged 2 weeks were not statistically different from each other but these diets were significantly lower in promoting weight change during week 3 . Thus, although the groups given fresh okra seed meal and 2-week-aged okra seed meal consumed the same amount of protein as the other test groups for the duration of the test period (table 4), these two groups showed a reduced weight gain during week 3 of the test period. Moreover, the group fed fresh okra seed meal lagged behind the other test groups during the last 2 weeks of the trial (fig. 2).

\section{DISCUSSION}

The results clearly show that okra seed meal can be used under some conditions as a feed for rats, but that under other conditions growth is not supported.

Ground okra seed that was prepared fresh daily and fed to rats for 21 days slowed growth development. Okra seed meal that had been heated 


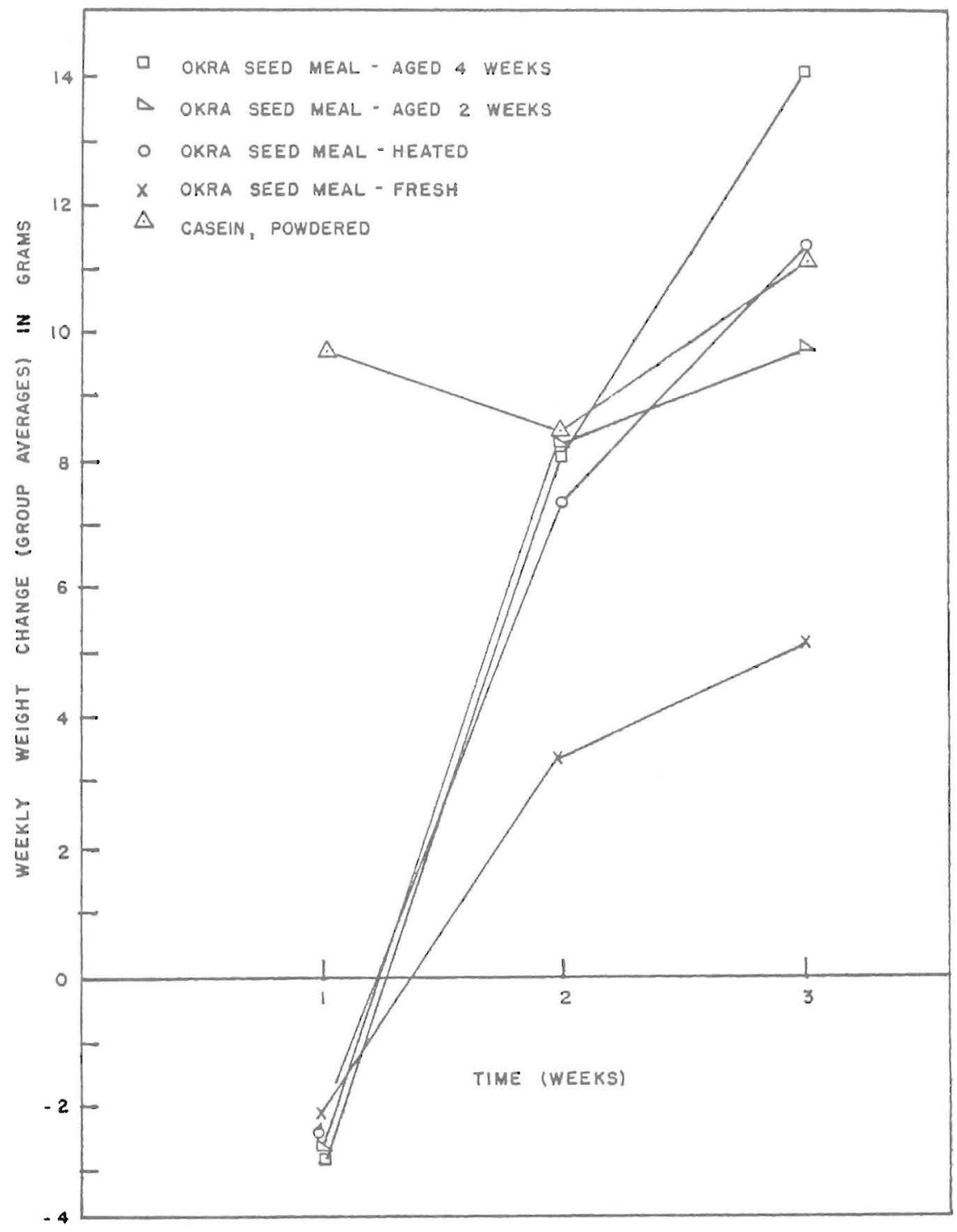

FIG. 2.-Weekly weight change vs. time in feeding trial 2.

before mixing the rat diet, or meal that had been aged at refrigerator temperature before the feeding trial, supported a faster growth response. The heating and/or aging of okra seed meal apparently altered or diminished some factor(s) in the meal that in the fresh state slowed growth in 
rats. It may be conjectured that a heat-labile factor that can also be oxidized during storage may be responsible for retarding growth.

The feeding trials included tests of okra seed meal in a powdered form and in an extruded form. This latter form provided a hardened and chunky product that the animals could grasp and ingest more easily than the powdered form. The feeding trial results indicated that texture or form of the food would produce a different PER value when fed to rats at the $10 \%$ level. The extruded okra seed product produced a $50 \%$ higher PER value than the powdered okra seed meal diet. However, when these diets were fed at varying protein level (RPV bioassay), the regression curve ratios of okra seed protein to casein were similar.

The relative protein value of okra seed indicated its value to be $70 \%$ of the casein control. This compared with similarly calculated relative nutritive values (RNV) for cottonseed (77\%), peanut meal (55\%), fish flour $(79.6 \%)$, high protein rice $(44.7 \%)$, and full fat soya flour $(64.8 \%)$ (1). The RPV bioassay more correctly showed the protein value of okra seed in maintaining and promoting growth in laboratory animals than the PER technique.

Karakoltsidis and Constantinides (2) reported the PER of okra seed as 3.45 compared to a PER of casein as 3.42. The adjusted PER values were 2.52 for okra seed and 2.50 for casein. In trial 1 of the present study the rat groups receiving approximately $10 \%$ protein levels of casein, powdered okra seed and extruded okra seed indicated the following PER values: casein 2.72, powdered okra seed 1.54, and extruded okra seed 2.35 . The adjusted PER values (casein equal to 2.50) are 1.05 for powdered okra and 1.62 for extruded okra seed meal.

The discrepancy between PER values of powdered okra seed of the Karakoltsidis and Constantinides (2) study and the present study is unexplained. The former values are unexpectedly high and subject to scrutiny.

The difference between the PER values of powdered and extruded okra seed diets in the first trial may partly be explained by a dose-dependency factor. Such dose-dependency is a major limitation of the PER assay in rating protein quality (7).

\section{RESUMEN}

El valor de la proteina de semilla de quimbombó (Abelmoschus esculentus (L.) Moench) en dietas para ratones se probó usando dos técnicas. La semilla se molió y se les sirvió en dietas balanceadas, fresca o almacenada, en polvo o en pelotas. La harina fresca inhibió el crecimiento de los ratones. La almacenada o preparada con calor en forma de pelotas sostenía el crecimiento. La manera de servir la harina influyó en la medida 
del valor de la proteína, porque influye en la cantidad ingerida. La proporción de eficiencia de la proteína ("protein efficiency ratio, PER") es más susceptible a tales cambios. El valor relativo de la proteína ("relative protein value, RPV") no está influido por la cantidad ingerida, por lo cual es una medida estable del valor de la proteína. La proteína de semilla de quimbombó compara muy favorablemente en valor nutritivo con proteinas de otras semillas.

\section{LITERATURE CITED}

1. Hegsted, D. M., Neff, R. and Worcester, J., 1968. Determination of the relative nutritive value of proteins, J. Agric. Food Chem. 16: 190.

2. Karakoltsidis, P. A. and Constantinides, S. M., 1975. Okra seeds: a new protein source, J. Agric. Food Chem. 23: 1204.

3. Kleinbaum, D. G. and Kupper, L. C., 1978. Applied Regression Analysis and Other Multivariate Methods, pp. 99-107. Duxbury Press, N. Scituate, MA.

4. Mangual-Crespo, G. and Martin, F. W., 1980. Effects of spacing on seed protein and oil production of four okra varieties, J. Agric. Univ. P. R. 64: 450-59.

5. Martin, F. W. and Ruberté, R., 1979. Milling and use of okra seed meal at the household level, J. Agric. Univ. P. R. 63: 1.

6. — Telek, L., Ruberte, R. and Santiago, A. G., 1979. Protein, oil, and gossypol content of a vegetable curd made from okra seeds, J. Food Sci. 44: 1529.

7. Samonds, K. W. and Hegsted, D. M., 1977. Animal bioassays: a critical evaluation with specific reference to assessing nutritive value for the human. In: "Evaluation of Protein for Humans," Ed, Bodwell, C. E., pp. 68-80. AVI Publishing Co., Westport, CT. 